\title{
PENORMAAN HUKUM ISLAM DALAM SISTEM HUKUM INDONESIA DITINJAU DARI AJARAN TEOLOGI HUKUM THOMAS AQUINAS
}

\author{
Dian Agung Wicaksono \\ Departemen Hukum Tata Negara, \\ Fakultas Hukum, Universitas Gadjah Mada \\ Email: dianagung@ugm.ac.id
}

\section{Abstrak}

Penormaan hukum Islam dalam sistem hukum Indonesia, yang diwujudkan dalam peraturan perundang-undangan menjadi indikasi bahwa hukum Islam telah menjadi bagian dari sistem hukum Indonesia. Hal ini menarik bila ditinjau menggunakan ajaran teologi hukum Thomas Aquinas yang mengenalkan adanya dikotomi hukum berdasarkan sumbernya, yaitu lex aeterna, lex naturalis, dan lex humana. Dikotomi tersebut menjadi pisau analisis untuk melihat pada titik mana hukum Islam dituangkan dalam sistem hukum Indonesia. Penelitian ini mengkaji eksistensi penormaan hukum Islam dalam peraturan perundang-undangan dari perspektif teologi hukum, dengan pertanyaan penelitian: (a) Apa justifikasi penormaan substansi hukum Islam dalam sistem hukum Indonesia? (b) Bagaimana penormaan substansi hukum Islam dalam sistem hukum Indonesia bila ditinjau dari ajaran teologi hukum Thomas Aquinas? Penelitian ini menggunakan metode yuridis normatif, dengan menganalisis data sekunder berupa peraturan perundang-undangan dan literatur yang terkait dengan penormaan hukum Islam dan ajaran teologi hukum Thomas Aquinas. Hasil dari penelitian ini menunjukkan bahwa justifikasi penormaan substansi hukum Islam dalam sistem hukum Indonesia memiliki pijakan yang kuat karena tertuang dalam Pancasila Sila "Ketuhanan yang Maha Esa" dan Pasal 29 UUD NRI Tahun 1945. Adapun penormaan substansi hukum Islam dalam sistem hukum Indonesia bila ditinjau dari ajaran teologi hukum Thomas Aquinas menunjukkan bahwa penormaan substansi hukum Islam dalam peraturan perundangundangan tidak serta merta menurunkan derajat hukum Islam, karena 
penuangan substansi hukum Islam dalam peraturan perundang-undangan tidak kemudian mentransformasikan lex aeterna menjadi lex humana.

Kata kunci: Penormaan; Hukum Islam; Teologi hukum; Thomas Aquinas..

\section{Abstract}

The arrangement of Islamic law in the Indonesian legal system, which is manifested in statutory regulations, is an indication that Islamic law has become part of the Indonesian legal system. This is interesting when viewed using Thomas Aquinas' legal theology which introduces a legal dichotomy based on its sources, namely lex aeterna, lex naturalist, and lex humana. The dichotomy becomes a perspective to see at what level Islamic law is embedded in the Indonesian legal system. This research examines the existence of arrangement of Islamic law in statutory regulations from the perspective of legal theology, with research questions: (a) What is the justification for the arrangement of Islamic law substance in the Indonesian legal system? (b) How is the arrangement of the substance of Islamic law in the Indonesian legal system when viewed from the teachings of Thomas Aquinas' legal theology? This is normative legal research, by analyzing secondary data in the form of laws and libraries related to the arrangement of Islamic law and the teachings of the legal theology of Thomas Aquinas. The results indicate that the justification for the arrangement of the substance of Islamic law in the Indonesian legal system has a strong foothold because it is stated in the Pancasila "God Almighty" and Article 29 of the 1945 Constitution of the Republic of Indonesia. The teachings of legal theology of Thomas Aquinas show that arrangement of the substance of Islamic law in statutory regulations does not necessarily reduce the degree of Islamic law, because the substance of Islamic law in statutory regulations does not transform lex aeterna into lex humana.

Keywords: Arrangement; Islamic law; Legal theology; Thomas Aquinas.

\section{PENDAHULUAN}

Keberadaan norma dengan substansi hukum Islam dalam sistem hukum Indonesia, yang diwujudkan dalam peraturan perundang-undangan di Indonesia menjadi indikasi bahwa hukum Islam telah menjadi bagian dari sistem hukum Indonesia. Hal ini menarik bila merujuk pada pemikiran Sudjito (2011) yang 
menyatakan bahwa terdapat permasalahan dalam ilmu hukum, terutama pada penolakan terhadap semua hal-hal yang bersifat teologis dan metafisis, yang mana kebudayaan atau nilai-nilai sosial sangat lekat dengan aspek-aspek ketuhanan. Hukum agama adalah hukum yang langsung berasal dari Tuhan, yang dalam perkembangannya semakin terpinggirkan karena karakter hukum negara yang individualis, liberalis, materialis, dan hedonis semakin dominan dan hegemonik (Sudjito, 2019b). Pendapat Sudjito tersebut memberikan isyarat implisit bahwa secara empiris norma agama, khususnya agama Islam, disadari atau tidak, telah menjadi bagian yang tidak terpisahkan dari sistem hukum Indonesia. Namun demikian, dalam perkembangannya hal tersebut menimbulkan diskursus karena dinilai menggabungkan aspek teologis dalam kehidupan bernegara. Diskursus tersebut secara nyata muncul, misalnya dari kajian yang mengangkat isu mengenai politisasi agama dalam hukum dan kebijakan di era reformasi Indonesia (Eddyono, 2019).

Terlepas dari berbagai diskursus dituangkannya substansi hukum Islam dalam peraturan perundang-undangan, namun harus dipahami bahwa hal tersebut memiliki landasan konstitusional yang kuat, yaitu Pancasila Sila "Ketuhanan yang Maha Esa" dan Pasal 29 Undang-Undang Dasar Negara Republik Indonesia Tahun 1945 (UUD NRI Tahun 1945) yang pada pokoknya menegaskan bahwa Negara berdasarkan Ketuhanan Yang Maha Esa dan Negara menjamin kemerdekaan tiap-tiap penduduk untuk memeluk agamanya masing-masing dan untuk beribadat menurut agama dan kepercayaannya itu. Kedua hal tersebut menjadi dasar legitimasi bagi penormaan hukum yang berasal dari agama (baca: hukum Islam) ke dalam hukum nasional melalui proses legislasi.

Frasa "menjamin" dalam Pasal 29 ayat (2) UUD NRI Tahun 1945 sebagai kata kerja aktif mengindikasikan bahwa Negara harus aktif dan berinisiatif memberikan jaminan dalam hal kemerdekaan tiap-tiap penduduk untuk memeluk agamanya masing-masing dan untuk beribadat menurut agamanya dan kepercayaannya. Hal tersebut bermakna bahwa Negara secara imperatif dan positif perlu 
mengeluarkan peraturan perundang-undangan yang sesuai dengan syariat agama-agama dan secara negatif dilarang mengeluarkan peraturan perundang-undangan yang bertentangan dengan syariat agama-agama (Usman, 2002).

Eksistensi norma dalam peraturan perundang-undangan dengan substansi hukum Islam perlu mendapatkan telaah lebih lanjut, terlebih bila dikaji dari perspektif filsafat hukum, yang menurut Sudjito didefinisikan sebagai institusi pencarian jawaban atas persoalan-persoalan yang dihadapi manusia, mulai dari persoalan ketuhanan, alam semesta, sampai manusia itu sendiri, sehingga hubungan manusia dengan manusia yang ditata melalui norma dan hukum yang ada menjadi salah satu bidang garapan filsafat hukum yang arahnya adalah kemajuan atau progresivitas hidup (Puri, 2017). Dalam kajian filsafat hukum, Sudjito (2017) menyebutkan terdapat pluralitas hukum yang mencakup lex aeterna, lex divina, lex natura, dan lex humana yang hingga kini masih ada. Pemikiran pluralitas hukum, sebagaimana dielaborasi oleh Sudjito, berangkat dari ajaran hukum alam Thomas Aquinas yang ditulis dalam Summa Theologiae (juga dikenal sebagai Summa Theologica), yang membagi hukum berdasarkan sumbernya, yaitu: (a) hukum alam yang bersumber dari Tuhan (irasional); dan (b) hukum alam yang bersumber dari rasio manusia, yang secara lebih rinci dibagi dalam 4 (empat) golongan, yaitu (Darmodiharjo \& Shidarta, 1995; Johan, 2018):

a. lex aeterna, merupakan rasio Tuhan sendiri yang mengatur segala hal dan merupakan sumber dari segala hukum. Rasio ini tidak dapat ditangkap oleh pancaindra manusia.

b. lex divina, merupakan bagian dari rasio Tuhan yang dapat ditangkap oleh manusia berdasarkan waktu diterimanya.

c. lex naturalis, merupakan hukum alam yang merupakan penjelmaan dari lex aeterna di dalam rasio manusia.

d. lex positivis, yaitu hukum yang berlaku dan merupakan pelaksanaan dari hukum alam (lex naturalis) dalam kehidupan manusia di dunia.

Lebih lanjut, Thomas Aquinas menjelaskan bahwa sejak dunia 
diatur oleh ketentuan-ketentuan yang ditetapkan Tuhan, seluruh masyarakat di alam semesta diatur oleh akal yang berasal dari Tuhan. Sekalipun demikian, tidak seluruh hukum Tuhan dapat diperoleh oleh manusia (Darmodiharjo \& Shidarta, 1995).

Mendasarkan pada dikotomi dalam pluralitas hukum tersebut, menjadi menarik untuk kemudian melihat apakah eksistensi penormaan hukum Islam dalam peraturan perundangundangan dapat dikualifikasikan sebagai lex aeterna/lex divina atau telah beralih menjadi lex positivis/lex humana? Pertanyaan ini menarik dikarenakan substansi hukum Islam yang dituangkan dalam norma peraturan perundang-undangan secara tidak langsung telah mengalami transformasi dari hukum Tuhan menjadi hukum buatan manusia. Hal ini menjadi fokus utama dari penelitian ini dalam rangka menjawab apakah betul telah terjadi transformasi tersebut bila ditinjau dari ajaran teologi hukum Thomas Aquinas, dengan pertanyaan penelitian: (a) Apa justifikasi penormaan substansi hukum Islam dalam sistem hukum Indonesia? (b) Bagaimana penormaan substansi hukum Islam dalam sistem hukum Indonesia bila ditinjau dari ajaran teologi hukum Thomas Aquinas?

Dalam rangka menjawab pertanyaan penelitian di atas, penelitian ini menggunakan pendekatan kualitatif. Rumusan masalah dijawab dengan menggunakan penelitian hukum normatif, dengan menggunakan data sekunder, yang mencakup bahan hukum primer dan bahan hukum sekunder. Pendekatan yang digunakan dalam penelitian ini adalah pendekatan peraturan perundang-undangan (statutory approach) dan pendekatan konseptual (conceptual approach). Pendekatan peraturan perundangundangan dilakukan dengan menjawab wujud penormaan substansi hukum Islam dalam sistem hukum Indonesia yang terwujud dalam peraturan perundang-undangan. Adapun, pendekatan konseptual digunakan untuk menelaah ajaran teologi hukum Thomas Aquinas yang digunakan sebagai batu uji dalam menganalisis eksistensi penormaan substansi hukum Islam dalam sistem hukum Indonesia. 
Dalam penelitian ini, data sekunder yang digunakan terdiri atas bahan hukum primer dan sekunder. Bahan hukum primer yang digunakan adalah berupa peraturan perundang-undangan yang memuat substansi hukum Islam. Adapun bahan hukum sekunder yang digunakan adalah berupa buku, jurnal, dan laporan penelitian yang membahas tentang ajaran teologi hukum Thomas Aquinas. Bahan hukum tersebut dikumpulkan melalui studi kepustakaan (library research).

Hasil dari studi kepustakaan tersebut diolah dan disajikan untuk kemudian dilakukan analisis. Analisis data dilakukan secara deskriptif-analitis. Berbagai data yang disajikan kemudian dikaji melalui penalaran deduktif (deductive reasoning). Hasil pengkajian tersebut kemudian disusun secara sistematis.

\section{PEMBAHASAN}

\section{Justifikasi Penormaan Substansi Hukum Islam dalam Sistem Hukum Indonesia}

Potret realitas empiris dalam sistem hukum Indonesia menunjukkan bahwa proses pembentukan peraturan perundangundangan tidak mengabaikan nilai atau prinsip yang dikenal dalam hukum Islam, misalnya dengan diundangkannya Undang-Undang Nomor 1 Tahun 1974 tentang Perkawinan yang mengadopsi fikih munakahat, penerbitan Instruksi Presiden Nomor 1 Tahun 1991 tentang Penyebarluasan Kompilasi Hukum Islam yang mengadopsi kaidah faraidh, dibentuknya beberapa Undang-Undang yang mengatur mengenai muamalah dalam arti khusus, berupa pengaturan mengenai keuangan syariah, antara lain: (a) UndangUndang Nomor 21 Tahun 2008 tentang Perbankan Syariah; (b) Undang-Undang Nomor 40 Tahun 2014 tentang Perasuransian, yang memberikan definisi prinsip syariah sebagai prinsip hukum Islam dalam kegiatan perasuransian; (c) Undang-Undang Nomor 1 Tahun 2016 tentang Penjaminan, yang menyebutkan prinsip syariah didefinisikan sebagai prinsip hukum Islam dalam kegiatan penjaminan; (d) Undang-Undang Nomor 2 Tahun 2009 tentang 
Lembaga Pembiayaan Ekspor Indonesia, yang mengatur hukum Islam sebagai dijadikan landasan dalam pembuatan perjanjian antara Lembaga Pembiayaan Ekspor Indonesia dengan pihak lain.

Bahkan dalam hukum nasional juga sudah terdapat beberapa pengaturan yang terkait dengan filantropi Islam, misalnya UndangUndang Nomor 23 Tahun 2011 tentang Pengelolaan Zakat, UndangUndang Nomor 41 Tahun 2004 tentang Wakaf, Undang-Undang Nomor 13 Tahun 2008 tentang Penyelenggaraan Ibadah Haji, Undang-Undang Nomor 34 Tahun 2014 tentang Pengelolaan Keuangan Haji. Dalam perkembangan terbaru bahkan yang diatur bukan hanya dalam konteks hukum perdata Islam, namun juga hukum pidana Islam (jinayah) pun telah diatur dalam hukum positif, walaupun hanya dalam level Peraturan Daerah, yaitu Qanun Aceh Nomor 6 Tahun 2014 tentang Hukum Jinayat, di mana ketentuan tersebut menginduk pada pengaturan dalam UndangUndang Nomor 11 Tahun 2006 tentang Pemerintahan Aceh. Berbagai pengaturan yang merujuk pada nilai dan prinsip hukum Islam tersebut menjadi indikasi bahwa negara mengakui hukum Islam sebagai salah satu sumber dalam legislasi hukum nasional, di samping hukum adat dan hukum barat.

Penormaan substansi hukum Islam dalam sistem hukum Indonesia tidak dapat dilepaskan dari diskursus hubungan negara dan agama dalam konteks ketatanegaraan Indonesia. Perdebatan mengenai hubungan antara negara dengan agama menjadi suatu isu penting apabila suatu negara memiliki sebuah agama yang dominan dianut oleh sebagian besar masyarakat di negara tersebut. Beberapa pertanyaan penting yang kemudian muncul dari kondisi tersebut adalah: (a) apa definisi negara mengenai agama? (b) Apa definisi agama mengenai negara? (c) Siapa yang berhak mendefinisikan dan menentukan agama? (d) Serta apa peran agama terhadap negara dan apa peran negara terhadap agama? (Umar, 2019). Keempat pertanyaan tersebut dapat menjadi landasan untuk mengetahui bagaimana sejatinya hubungan antara negara dengan agama dalam konteks Indonesia. Dengan melihat konstruksi hubungan negara dengan agama di Indonesia, dapat ditarik benang 
merah untuk melihat justifikasi penormaan hukum Islam dalam sistem hukum nasional.

Dari perspektif historis, hubungan antara negara dengan agama merupakan hubungan dualistis. Di satu sisi, negara memberikan legitimasi bagi agama, dan di sisi lain agama menjadi legitimasi bagi negara (A. Wahid, 1999a). Dalam posisi tambahan, hubungan antara negara dengan agama dapat menjadi manipulatif, yang mana hanya menjadikan simbol agama sebagai legitimasi dari kekuasaan (A. Wahid, 1999b). Bentuk hubungan negara dan agama seharusnya menggunakan perspektif fungsionalitas, yang mana agama dan negara memiliki fungsi sosial di masyarakat (A. Wahid, 1999a). Dengan demikian, meskipun negara dan agama memiliki perbedaan fungsi, keduanya tidak dapat saling meniadakan (Fitriah, 2013).

Kemudian, secara teoritis terdapat tiga jenis paradigma dalam kaitannya dengan hubungan antara negara dan agama, yakni (M. Wahid \& Rumadi, 2001):

a. Paradigma integralistik atau terpadu. Dalam pandangan ini, negara dan agama terintegrasi. Negara didasarkan pada kedaulatan Tuhan, dan negara merupakan institusi yang terintegrasi yang mengombinasikan institusi politik dengan institusi agama. Sumber hukumnya adalah ketentuanketentuan agama.

b. Paradigma Simbiotik. Berdasarkan paradigma ini, terdapat hubungan timbal balik antara agama dan negara. Di satu sisi, agama membutuhkan kebijakan negara untuk berkembang, namun di sisi lain, negara membutuhkan agama untuk mendapatkan panduan moral dan etika. Dalam pandangan ini, ketentuan-ketentuan dari agama yang dominan dapat mempengaruhi hukum negara, atau dapat diadopsi dalam peraturan perundang-undangan. Dengan demikian, negara dan agama memiliki keterkaitan yang fungsional.

c. Paradigma Sekularistik. Pandangan ini menolak adanya hubungan antara negara dan agama. Gagasan utama dari 
paradigma sekularistik adalah memisahkan negara dengan agama, sehingga negara tidak menggunakan agama sebagai instrumen politik. Lebih lanjut, tidak ada ketentuan agama yang diatur dalam peraturan perundang-undangan. Agama merupakan urusan individu dan tidak terkait dengan negara, sehingga semua agama adalah setara dan tidak ada yang diistimewakan.

Lebih lanjut, dalam kaitannya dengan paradigma integralistik, Parakitri T. Simbolon menjelaskan tiga jenis hubungan antara negara dan agama dalam konteks paradigma integralistik, yaitu (Aur, 2014; Kristanto \& Arsuka, 2002):

a. Model Integralistik Simetris. Dalam model ini, hubungan antara negara dan agama tidak dapat dipisahkan satu dengan lainnya. Keduanya terintegrasi dalam satu tubuh, atau secara umum disebut sebagai teokrasi. Contohnya, Vatikan dan Saudi Arabia. Dalam perkembangannya, negara teokrasi dapat dibagi menjadi dua jenis, yakni negara teokrasi langsung dan negara teokrasi tidak langsung. Negara teokrasi langsung percaya bahwa pemerintah merupakan kekuasaan dari Tuhan, sedangkan teokrasi tidak langsung percaya bahwa pemerintah bukanlah kekuasaan Tuhan, hanya kepala negara saja yang diutus oleh Tuhan.

b. Model Integralistik Asimetris. Dalam model ini, hubungan antara negara dan agama dapat terbagi menjadi dua jenis, yakni "agama dalam negara" atau "negara dalam agama". Pada bentuk pertama, agama harus tunduk pada kekuasaan negara, meskipun agama dapat mengintervensi kebijakan negara, begitu pula sebaliknya pada bentuk kedua. Negara yang mengimplementasikan model ini adalah UK dan Pakistan.

c. Model Sipil. Pada Model Sipil, terdapat dua kondisi yang terjadi: dalam kondisi formal, negara dan agama terpisah, namun dalam praktiknya, satu atau lebih agama mendominasi. Sebagai contoh, model ini diadopsi di 
Malaysia, Brunei, Filipina, dan Indonesia. Malaysia dan Brunei menentukan apa yang menjadi agama negara, tetapi tetap melindungi agama-agama lain untuk berkembang. Sedangkan Filipina dan Indonesia mengakui pluralitas agama dengan satu agama yang lebih dominan.

Dalam konteks Indonesia, hubungan antara negara dengan agama tidak pernah secara tegas diatur dalam konstitusi Indonesia (Siregar, 2008). Bachtiar Effendy (2011) dalam disertasinya menyatakan sebagai berikut:

Polemik antara Soekarno dan Natsir merupakan perdebatan yang tidak ada akhirnya dan masih dapat dieksplorasi. Keduanya tidak memiliki niatan untuk memformulasikan konsepsi antara negara dengan agama yang siap digunakan. Mereka juga tidak memiliki niatan untuk mencari kesamaan di antara argumen-argumen mereka (kalimah sawấ). Keduanya hanya menunjukkan posisi ideologis-politis mereka. Konsekuensinya, perdebatan yang terjadi hanya menyoroti perbedaan yang tidak terpecahkan dari keduanya.

Lebih lanjut, berdasarkan risalah pembentukan UUD NRI Tahun 1945 di atas, sebagaimana dikutip oleh Bachtiar Effendy, dapat dikatakan pula bahwa Indonesia tidak memiliki konsep yang jelas mengenai hubungan antara negara dan agama, sehingga menjadi terlihat pula mengapa ketentuan dalam UUD NRI Tahun 1945 tidak menyebutkan secara jelas pola atau model hubungan antara negara dengan agama.

Hubungan antara negara dengan agama dalam konstitusi Indonesia hanya diatur dalam Pasal 29 UUD NRI Tahun 1945. Pasal a quo merupakan salah satu pasal yang tidak diubah dalam proses amandemen UUD NRI Tahun 1945 yang dilakukan pada tahun 1999 sampai 2002. Ada pun pasal tersebut menyatakan bahwa: (1) Negara berdasar atas Ketuhanan Yang Maha Esa; dan (2) Negara menjamin kemerdekaan tiap-tiap penduduk untuk memeluk agamanya masing-masing dan untuk beribadat menurut agamanya dan kepercayaannya itu. 
Selain itu, terdapat pula beberapa ketentuan konstitusional yang terkait pula dengan agama yang ditambahkan pada saat amandemen, yakni Pasal 28E dan Pasal 28I. Dalam Pasal 28E, secara spesifik yang terkait dengan agama dapat dilihat pada ayat (1) yang menyatakan bahwa setiap orang berhak memeluk agama dan beribadat menurut agamanya, dan pada ayat (2) yang menyatakan setiap orang berhak atas kebebasan meyakini kepercayaan sesuai dengan hati nuraninya. Sedangkan dalam Pasal 28I ayat (1), dinyatakan bahwa hak beragama merupakan salah satu hak yang tidak dapat dikurangi dalam keadaan apapun.

Ketentuan-ketentuan di atas menunjukkan adanya mandat konstitusional kepada negara untuk wajib menghormati, melindungi, dan memenuhi hak untuk beragama. Negara tidak dapat mengintervensi langsung praktik atau ritual keagamaan, tetapi negara dapat mengambil peran dalam urusan keagamaan, tidak lain adalah untuk memastikan pemenuhan hak beragama. Sebagai contoh, dapat dilihat dalam peraturan perundangundangan mengenai zakat, perkawinan, dan haji, kemudian penentuan awal bulan Ramadhan, serta upaya untuk mengamankan acara maupun perayaan keagamaan, serta keterlibatan lain dari negara dalam berbagai urusan agama.

Lebih lanjut, berbagai ketentuan tersebut sejatinya sejalan dengan konsep Negara Hukum Pancasila yang diperkenalkan oleh konstitusi Indonesia sebagai hukum prismatik di antara berbagai konsep negara hukum yang mengombinasikan berbagai konsep negara hukum yang relevan dengan kondisi Indonesia (Wicaksono, 2013). Negara Hukum Pancasila mengandung tidak hanya kombinasi elemen-elemen dari konsep rechtsstaat dan rule of law, tetapi juga terdapat konsep socialist legality dan Islamic nomocracy. Tidak hanya itu, Negara Hukum Pancasila memiliki elemen unik yang mengombinasikan prinsip ketuhanan (yang berasal dari konsep Islamic nomocracy, sehingga tidak ada pemisahan antara negara dan agama), demokrasi permusyawaratan, keadilan sosial, dan persatuan Indonesia (Zoelva, 2009). 
Dalam konteks hubungan antara negara dengan agama di Indonesia, Moh. Mahfud MD (2011) memilih sebuah nomenklatur "negara nasionalis religius", yakni Indonesia bukanlah negara agama, tetapi Indonesia merupakan negara memiliki prinsip ketuhanan. Mengacu pada pidato Soekarno, setiap warga negara di Indonesia harus memiliki Tuhan dan Indonesia adalah negara yang memiliki Tuhan (Soekarno, 1945). Maka dari itu, meskipun Indonesia bukan negara agama, akan tetapi setiap warga negara diwajibkan untuk bertuhan. Akan tetapi, negara tidak dapat mengatur bagaimana warga negara beribadah kepada Tuhannya. Lebih lanjut, dalam konstruksi urusan pemerintahan, agama menjadi salah satu urusan pemerintahan yang disebutkan secara eksplisit menjadi urusan pemerintahan absolut, yakni urusan pemerintahan yang sepenuhnya menjadi kewenangan pemerintah pusat, sebagaimana diatur pada Pasal 9 ayat (2) dan Pasal 10 ayat (1) huruf f Undang-Undang Nomor 23 Tahun 2014 tentang Pemerintahan Daerah.

Apabila dilihat secara historis yuridis, berdasarkan konstruksi ketentuan mengenai agama dalam UUD NRI Tahun 1945 serta berbagai dinamika yang terjadi selama proses pembentukan maupun pada saat pelaksanaannya, dapat dilihat bahwa sejatinya hubungan antara negara dan agama di Indonesia sangat dekat dan terkait. Adanya ketentuan konstitusional yang menyatakan bahwa negara berdasar atas Ketuhanan Yang Maha Esa dan adanya jaminan kemerdekaan untuk memeluk agama dan beribadat menurut agamanya masing-masing, dapat menjadi justifikasi konstitusional untuk menuangkan berbagai substansi hukum Islam dalam sistem hukum nasional. Tujuannya semata-mata adalah untuk menjamin terpenuhinya hak warga negara untuk dapat beragama sebagaimana telah diatur dalam konstitusi Indonesia, khususnya bagi yang beragama Islam. Dengan demikian, berbagai ketentuan hukum Islam dapat diadopsi menjadi sumber hukum di Indonesia, yakni melalui penormaan dalam peraturan perundangundangan. 


\section{Penormaan Substansi Hukum Islam dalam Sistem Hukum Indonesia Ditinjau dari Ajaran Teologi Hukum Thomas Aquinas}

Lebih lanjut, setelah dielaborasikan justifikasi penormaan substansi hukum Islam dalam sistem hukum Indonesia, pada bagian ini akan ditelaah bagaimana penuangan substansi hukum Islam dalam sistem hukum Indonesia bila ditinjau dari perspektif filsafat hukum, khususnya dengan mengacu pada ajaran teologi hukum Thomas Aquinas. Mengutip pendapat Sudjito (2007), teologi hukum sesungguhnya merupakan konsep hukum klasik yang berlaku sepanjang waktu dan senantiasa dibutuhkan kehadirannya sebagai dasar, penuntun, penjaga, dan sekaligus obat bagi ketidaksempurnaan hukum, dikarenakan ciri-ciri yang melekat padanya, sebagai berikut: (a) teologi hukum merupakan seperangkat norma-moral sosial; (b) teologi hukum merupakan realitas kodrati, universal; (c) teologi hukum bersifat normatif, eksis di alam sollen dan bersifat a priori; (d) teologi hukum berfungsi sebagai pengarah, kontrol, dan ukuran terhadap perilaku manusia.

Dengan mengacu pada pemikiran Sudjito tersebut, maka dalam melihat keberadaan penormaan substansi hukum Islam dalam sistem hukum Indonesia, menjadi hal yang menarik untuk ditelaah lebih lanjut, apakah dengan demikian keberadaan normanorma dengan substansi hukum Islam dalam hukum positif di Indonesia mengindikasikan telah sesuainya dengan ajaran teologi hukum Thomas Aquinas? Terlebih lagi bila menggunakan dikotomi jenis hukum sebagaimana telah diuraikan di bagian Pendahuluan, apakah penuangan substansi hukum Islam dalam hukum positif dapat dimaknai telah mentransformasikan hukum Tuhan menjadi hukum buatan manusia yang mutatis mutandis menjadikan hukum positif di Indonesia sejalan dengan ajaran teologi hukum Thomas Aquinas? Sebelum menjawab pertanyaan-pertanyaan tersebut, lebih tepat bila kemudian memahami ratio d'etre pemikiran Thomas Aquinas dengan memahami latar belakang personalnya. 
Dengan mengutip elaborasi Adrianus Sunarko (2016) diperoleh pemahaman mengenai latar belakang Thomas Aquinas sebagai berikut:

Thomas Aquinas dilahirkan pada tahun 1225 di Roccasecca (antara Roma dan Napoli) sebagai anak bungsu dari bangsawan Landulf von Aquino. Pada usia 5 tahun Thomas dibawa ke biara para rahib Benediktin di Montecassino. Hingga usia 14 tahun ia dididik dan dibesarkan dalam semangat para rahib benediktin. Karena alasan perang Thomas Aquinas terpaksa meninggalkan Montecassino pada tahun 1239 dan oleh keluarganya dikirim untuk belajar (artes liberales) di universitas Napoli yang didirikan pada tahun 1224. Di sanalah melalui Petrus von Hibernia ia mulai berkenalan dengan pemikiran Aristoteles. Di Napoli juga Thomas Aquinas memulai kontak pertama dengan Ordo Predicatorum (Ordo Pengkotbah) yang didirikan oleh St. Dominikus dari Spanyol pada tahun 1216. Pada tahun 1243, meskipun ditentang keluarganya, Thomas Aquinas memutuskan menjadi anggota ordo tersebut. Sesungguhnya langkah menjadi anggota Ordo Predicatorum ini merupakan langkah penting dan menentukan bagi Thomas. Sejak tahun 1245, Thomas Aquinas pergi ke Paris untuk belajar dan dari sana pada tahun 1248 bersama gurunya Albertus Agung pindah ke Koeln (Jerman), di mana Thomas Aquinas kemudian ditahbiskan. Di Koeln, Thomas Aquinas kemudian sempat memberi kuliah singkat tentang Kitab Suci sebelum kemudian atas saran para gurunya pada tahun 1252, Thomas Aquinas dipanggil ke Paris. Pada tahun 1257, Thomas Aquinas menjadi Magister (Profesor) di Paris. Dua tahun kemudian, Thomas Aquinas dipanggil ke Roma dan sejak tahun 1259 sampai dengan 1268 memberi kuliah bagi para dominikan. Sejak 1269 hingga 1272, Thomas Aquinas kembali ke Paris untuk kedua kalinya, terlibat dalam kehidupan akademis di sana antara lain berkaitan dengan penerimaan filsafat Aristoteles dalam refleksi teologis (antara lain perdebatan dengan aliran Ibnu Rusyd serta dengan penganut Agustinus konservatif). Pada 1272, Thomas Aquinas kembali ke Napoli dan mendirikan akademi milik 
Ordonya. Di sinilah Thomas Aquinas menyelesaikan karya utama teologinya yang sudah dimulainya sejak 1266, yaitu Summa Theologiae. Paus Gregorius XX memanggil Thomas Aquinas pada tahun 1274 untuk ikut dalam konsili di Lyon, tetapi Thomas Aquinas meninggal dalam perjalanan, yaitu di sebuah biara sistersiensis di Fossanuova (antara Roma dan Napoli) pada 7 Maret 1274 dalam usia 49 tahun. Karya-karyanya yang banyak dapat dibagi dalam empat kelompok: (a) Komentar, yaitu 13 komentar atas tulisan-tulisan Aristoteles, 9 komentar atas Kitab Suci, dan komentar atas karya-karya Dionysius Areopagita dan Boethius; (b) Karya-karya sistematis, yaitu komentar atas "Sententia" dari Petrus Lombardus (1253-1256), Summa contra Gentiles (1259-1266), Summa Theologiae (1266-1273), Compendium Theologiae; (c) Quaestiones disputatae, yaitu Kumpulan berbagai macam disputatio yang pernah disampaikan Thomas Aquinas, terdapat 7 kumpulan disputatio dengan jumlah 63 disputatio, yang terdiri dari 510 artikel; dan (d) Opuscula, yaitu tulisan-tulisan kecil filsafat dan teologi: De Ente et Essentiale, Contra Errores Graecorum (1263) yang ditujukan pada Paus Urbanus IV, uraian khotbah berkaitan dengan Doa Bapa Kami dan Ave Maria, serta himne yang ditulis Thomas Aquinas tentang Ekaristi ketika pesta tubuh dan darah Tuhan (1264).

Kebesaran Thomas Aquinas tidak terletak dalam orisinalitasnya, melainkan dalam kemampuannya untuk mempersatukan unsur-unsur utama para pemikir agung yang mendahuluinya dalam satu sistem harmonis yang sebagai sistem itu, lantas merupakan sesuatu yang baru dan universal serta lebih mendalam dan matang daripada paham-paham asli itu sendiri (Suseno, 2003).

Thomas Aquinas adalah seorang pemikir abad pertengahan dan rohaniwan gereja Katolik yang lahir di Italia, seorang doktor filsafat dan teologi, yang dalam membahas arti hukum Aquinas mulai membedakan antara hukum yang berasal dari wahyu dan hukum yang dijangkau oleh akal budi manusia itu sendiri (Hanafi, 2018). Thomas Aquinas, yang dikenal sebagai penerus tradisi filsafat ala Aristoteles, sampai tingkat tertentu meneruskan garis 
pemikiran Aristoteles dan juga Kaum Stoa. Menurut Kaum Stoa, manusia adalah makhluk rasional yang diciptakan Tuhan sesuai dengan hakikatnya dan akal budi terdapat pada manusia, maka hal yang pertama yang dimiliki secara barusan oleh manusia dan Tuhan adalah akal budi (Hanafi, 2018). Thomas Aquinas memberikan pengertian hukum sebagai "quendam rationis ordinatio ad bonum commune, a beo curam communitatis habet, promulgata" (perintah yang masuk akal, yang ditujukan kesejahteraan umum, dibuat oleh mereka yang mengemban tugas suatu masyarakat dan dipromulgasikan atau diundangkan) (Rosadi, 2010; Sardi, 2002).

Thomas Aquinas membedakan tiga hukum, yaitu (Sunarko, 2016):

1. Hukum abadi (lex aeterna)

Hukum abadi menunjuk pada kebijaksanaan kekal dari Allah sendiri yang menciptakan seluruh alam semesta serta penghuninya. Segala sesuatu yang ada di dalam alam semesta dan terjadi di dalamnya berlangsung mengikuti hukum abadi.

2. Hukum kodrat (lex naturalis)

Hukum kodrat identik dengan hukum alam. Adapun manusia di satu pihak 'terikat' pada hukum alam yang melekat padanya. Tetapi di lain pihak memiliki kebebasan. Manusia tidak secara buta dan niscaya mengikuti faktorfaktor alamiah, tetapi dapat mengambil jarak dan bersikap terhadap faktor-faktor tersebut. Jadi, berkaitan dengan manusia, hukum kodrat tidak bekerja secara niscaya, tetapi merupakan hukum dalam arti seruan normatif yang di satu pihak wajib dilakukan, tetapi juga dapat diabaikan. Sebagai teori etis, hukum kodrat menunjuk pada dasar kewajiban moral dan menjawab pertanyaan tentang bagaimana manusia harus bertindak. Hukum kodrat adalah dasar dari segala kewajiban manusia. Kewajiban moral dasar manusia (yang menjadi landasan dari berbagai kewajiban lain) adalah hidup dan bertindak sesuai dengan kodrat. Dan karena kodrat itu dapat diketahui dengan akal budi, maka 
sebenarnya setiap orang mengetahui bagaimana dia harus hidup. Sebenarnya yang dimaksud dengan kodrat atau hukum kodrat itu adalah sesuatu yang aktual. Kodrat manusia tidak lain adalah kemanusiaan kita sendiri. Hidup sesuai dengan kodrat berarti hidup sesuai dengan martabat manusia.

3. Hukum positif (lex humana).

Hukum ketiga adalah hukum manusia, hukum positif. Hukum positif harus sesuai dengan hukum kodrat. Kalau hukum positif bertentangan dengan hukum kodrat maka tidak perlu ditaati. Prinsip hukum kodrat itu diterapkan Thomas Aquinas untuk teorinya tentang negara. Peraturanperaturan yang dibuat negara harus sesuai dan berdasarkan pada hukum kodrat manusia. Jika tidak atau bertentangan dengan hukum kodrat, hukum positif yang dikeluarkan negara tidak memiliki daya ikat. Lebih dari itu, menurut Thomas Aquinas eksistensi negara itu bersumber dari kodrat manusia. Manusia adalah makhluk sosial. Untuk hidup secara baik manusia memerlukan manusia lain. Negara adalah pelembagaan dimensi sosial manusia yang dapat membantu manusia untuk memenuhi berbagai kebutuhan manusia untuk hidup secara baik dan beradab. Dengan kata lain, Thomas Aquinas menghubungkan tujuan adanya negara dengan tujuan hidup manusia itu sendiri. Menurut Thomas ada tiga tujuan hidup manusia: (a) hidup dalam arti tidak mati (vivere); (b) hidup dengan baik (bene vivere), artinya hidup sesuai dengan kekayaan kebutuhan manusia yang beragam; (c) tujuan hidup manusia terakhir adalah kebahagiaan abadi (beate vivere). Tujuan negara tidak lain adalah mendukung tercapainya ketiga tujuan tersebut (khususnya aspek kedua dan ketiga). Negara bertugas mengupayakan agar kebutuhan manusia (satu dan dua) dapat dipenuhi. Tetapi negara juga perlu menciptakan kondisi agar manusia dapat mengupayakan kebahagiaan abadi. 
Mendasarkan pada pemaparan di atas, dapat dilihat sejatinya pemikiran Thomas Aquinas sejatinya hanya membedakan hukum dalam 3 jenis, yaitu lex aeterna, lex naturalis, dan lex humana. Adapun terminologi lex divina merupakan diksi substitutif dari lex aeterna yang berarti hukum Tuhan yang suci, sedangkan lex positivis merupakan diksi substitutif dari lex humana yang bermakna hukum buatan manusia yang berlaku, yang mana pada prinsipnya tiap diksi substitusi tersebut memiliki kesamaan makna dan substansi (Chroust, 1941; Chroust \& Collins Jr., 1941; Elders, 2019; Kossel, 2002).

Berbekal pemahaman di atas, maka dalam menelaah eksistensi penormaan substansi hukum Islam dalam sistem hukum Indonesia dengan menggunakan kacamata ajaran teologi hukum Thomas Aquinas, setidaknya dapat disintesis beberapa catatan sebagai berikut: Catatan Pertama, perlu pemahaman konstektual terhadap ajaran teologi hukum Thomas Aquinas dan kesesuaian penerapan konsep teologi hukum Thomas Aquinas disandarkan pada ruang lingkup pemaknaan. Bukan dalam kerangka membuat dikotomi berbasis agama, namun harus disadari bahwa pemikiran Thomas Aquinas tumbuh dan berkembang dalam ajaran gereja Katolik, yang memungkinkan lahirnya perbedaan persepsi dalam memaknai hakikat dan substansi "hukum Tuhan" dalam konteks hukum Islam dan hukum Gereja. Mengutip pendapat Johannes Ludwig Chrysostomus Abineno (1994), hukum gereja adalah ilmu yang mempelajari dan menguraikan segala peraturan dan penetapan yang digunakan oleh Gereja untuk menata dan mengatur hidup dan pelayanannya di dunia. Pada sisi yang lain, hukum Islam dimaknai dalam konteks: (a) syariah, baik yang ditetapkan langsung dalam Al-Qur'an dan Sunnah, maupun yang telah dicampuri oleh pemikiran manusia (ijtihad) (Djamil, 1997; Fauzi, 2018); dan (b) fikih, merupakan wahyu Illahi dan mencakup semua kebutuhan kehidupan yang bersifat agamis dan memperhatikan kemaslahatan pribadi dan masyarakat (Fauzi, 2018). 
Mencermati kedua pendefinisian di atas, setidaknya telah tergambar bahwa terdapat perbedaan yang relatif diametral diantara dua jenis "hukum Tuhan" tersebut. Oleh karena itu, dalam kerangka memahami konsep teologi hukum Thomas Aquinas diperlukan konteks yang tepat untuk melihat penerapannya dalam penormaan substansi hukum Islam dalam sistem hukum Indonesia. Apakah memang konsep teologi hukum Thomas Aquinas menginginkan keberadaan lex aeterna eksis sebagai "hukum Tuhan" an sich yang dapat dibedakan secara dikotomis terpisah dari penjabarannya dalam lex humana? Ataukah konsep teologi hukum Thomas Aquinas membuka ruang lebih longgar untuk melihat eksistensi lex aeterna dalam tataran yang lebih operasional menjadi satu kesatuan dengan lex humana dalam hukum positif suatu negara? Dalam konteks yang lebih operasional ini, perlu dilihat kembali apakah konsep teologi hukum Thomas Aquinas menghendaki "hukum Tuhan" dituangkan secara eksplisit-literal ataukah cukup secara implisit-substantif dalam hukum positif suatu negara?

Dengan menggunakan kerangka berpikir tersebut, maka penormaan substansi hukum Islam dalam sistem hukum Indonesia yang diwujudkan dalam peraturan perundang-undangan dapat dimaknai sebagai bentuk kesesuaian dan penerapan dengan konsep teologi hukum Thomas Aquinas dalam sistem hukum Indonesia. Hal ini dikarenakan substansi hukum Islam yang menyebar, baik pada lapangan hukum privat maupun pada lapangan hukum publik, dituangkan dengan intensitas dan literalitas yang beragam. Pada salah satu aspek pengaturan terlihat sangat eksplisit-literal, namun pada aspek pengaturan yang lain berupa implisit-substantif. Variasi penuangan substansi hukum Islam dalam sistem hukum Indonesia menjadi petunjuk bahwa sejatinya konsep teologi hukum Thomas Aquinas disadari atau tidak telah diterapkan dalam sistem hukum Indonesia.

Bahkan bila menggunakan konsep al-maqashid as-syariah, substansi hukum Islam tidak perlu ditegaskan secara eksplisitliteral dalam bentuk norma pengaturan, namun cukup dengan 
adanya kesesuaian semangat pengaturan dengan tujuan keberadaan hukum Islam, yaitu untuk mewujudkan kebaikan sekaligus menghindarkan keburukan, atau menarik manfaat dan menolak mudharat (Shidi, 2009). Al-maqashid as-syariah adalah untuk kemaslahatan manusia (Jumantoro, 2005), karena tujuan utama dari syariah adalah untuk menjaga dan memastikan bahwa kemaslahatan kaum muslimin, baik di dunia maupun di akhirat, terwujud dengan cara terbaik dengan memelihara (Hallaq, 2001): (1) agama, (2) jiwa, (3) akal, (4) keturunan, dan (5) harta.

Catatan Kedua, penormaan substansi hukum Islam dalam peraturan perundang-undangan tidak serta merta menurunkan derajat hukum Islam. Pemahaman ini menjadi penting untuk menjawab pertanyaan apakah eksistensi penormaan hukum Islam dalam peraturan perundang-undangan dapat dikualifikasikan telah terjadi transformasi dari lex aeterna menjadi lex humana? Dengan mendasarkan pada kerangka konsep teologi hukum Thomas Aquinas dapat dijelaskan bahwa penuangan substansi hukum Islam dalam peraturan perundang-undangan tidak kemudian mentransformasikan lex aeterna menjadi lex humana. Hukum Tuhan (lex aeterna) tidak serta merta kehilangan kesucian dan kemuliaannya ketika dituangkan dalam peraturan perundangundangan buatan manusia (lex humana).

Hal yang membedakan keduanya hanyalah basis kekuatan mengikatnya. Substansi lex aeterna memiliki kekuatan mengikat terhadap manusia alamiah dengan disandarkan pada keimanan yang bersifat intangible, yang sepenuhnya menjadi domain personal manusia dan Tuhan. Adapun lex humana memiliki kekuatan mengikat terhadap manusia dalam konstruksi sebagai subyek hukum yang dipaksa untuk tunduk secara normatif oleh organisasi kekuasaan dengan ancaman sanksi yang bersifat tangible. Dengan demikian, keberadaan substansi hukum Islam dalam sistem hukum Indonesia yang diwujudkan dengan penuangannya dalam peraturan perundang-undangan tidak serta merta menjadikan substansi hukum Islam kehilangan kemuliaannya karena bertransformasi dari lex aeterna menjadi lex humana. 
Justru eksistensi tersebut menjadikan hukum Islam menjadi hukum yang hidup dan mewarnai kehidupan bernegara Indonesia dan menghasilkan kekuatan hukum yang mampu menembus segala dimensi wujud (Sudjito, 2019a). Dalam konteks dimensi vertikal, eksistensi hukum Islam tersebut juga dapat dimaknai sebagai upaya untuk memahami semua kehendak Tuhan Yang Maha Esa, untuk selanjutnya taat dan patuh menjalankan perintahNya serta berupaya menjauhi laranganNya, atau dengan perkataan lain telah menjadi manusia Pancasilais, yaitu manusia yang bertakwa kepada Tuhan Yang Maha Esa (Sudjito, 2016).

\section{KESIMPULAN}

Berdasarkan elaborasi dan analisis di atas, dapat disimpulkan sebagai berikut: Pertama, justifikasi penormaan substansi hukum Islam dalam sistem hukum Indonesia memiliki pijakan yang kuat karena tertuang dalam Pancasila Sila "Ketuhanan yang Maha Esa" dan Pasal 29 UUD NRI Tahun 1945 yang pada pokoknya menegaskan bahwa Negara berdasarkan Ketuhanan Yang Maha Esa dan Negara menjamin kemerdekaan tiap-tiap penduduk untuk memeluk agamanya masing-masing dan untuk beribadat menurut agamanya dan kepercayaannya itu. Kedua hal tersebut menjadi dasar legitimasi bagi penormaan hukum Islam ke dalam sistem hukum Indonesia.

Kedua, penormaan substansi hukum Islam dalam sistem hukum Indonesia bila ditinjau dari ajaran teologi hukum Thomas Aquinas setidaknya dapat dilihat dalam 2 (dua) catatan, yaitu: (a) perlu pemahaman konstektual terhadap ajaran teologi hukum Thomas Aquinas dan kesesuaian penerapan konsep teologi hukum Thomas Aquinas disandarkan pada ruang lingkup pemaknaan, maksudnya adalah harus disadari bahwa pemikiran Thomas Aquinas tumbuh dan berkembang dalam ajaran gereja Katolik, yang memungkinkan lahirnya perbedaan persepsi dalam memaknai hakikat dan substansi "hukum Tuhan" dalam konteks hukum Islam dan hukum Gereja; dan (b) penormaan substansi hukum Islam dalam peraturan perundang-undangan tidak serta 
merta menurunkan derajat hukum Islam, karena dengan mendasarkan pada kerangka konsep teologi hukum Thomas Aquinas dapat dijelaskan bahwa penuangan substansi hukum Islam dalam peraturan perundang-undangan tidak kemudian mentransformasikan lex aeterna menjadi lex humana. Hukum Tuhan (lex aeterna) tidak serta merta kehilangan kesucian dan kemuliannya ketika dituangkan dalam peraturan perundang-undangan buatan manusia (lex humana). Hal yang membedakan keduanya hanyalah basis kekuatan mengikatnya, yaitu lex aeterna memiliki kekuatan mengikat terhadap manusia alamiah dengan disandarkan pada keimanan yang bersifat intangible, yang sepenuhnya menjadi domain personal manusia dan Tuhan, sedangkan lex humana memiliki kekuatan mengikat terhadap manusia dalam konstruksi sebagai subyek hukum yang dipaksa untuk tunduk secara normatif oleh organisasi kekuasaan dengan ancaman sanksi yang bersifat tangible.

\section{DAFTAR PUSTAKA}

Abineno, J. L. C. (1994). Garis-Garis Besar Hukum Gereja. Jakarta: BPK Gunung Mulia.

Aur, A. (2014). Dialog Negara Hukum Demokratis dan Agama: Memotret Deliberasi Politik Berbasis Agama di Indonesia dengan Perspektif Filsafat Politik Jürgen Habermas. Jurnal Ultima Humaniora, 2(1).

Chroust, A.-H. (1941). Ius Gentium in the Philosophy of Law of St. Thomas Aquinas. Notre Dame Law Review, 17(1).

Chroust, A.-H., \& Collins Jr., F. A. (1941). The Basic Ideas in the Philosophy of Law of St. Thomas Aquinas as Found in the Summa Theologica. Marquette Law Review, 26(1).

Darmodiharjo, D., \& Shidarta. (1995). Pokok-Pokok Filsafat Hukum: Apa dan Bagaimana Filsafat Hukum Indonesia. Yogyakarta: Gramedia Pustaka Utama.

Djamil, F. (1997). Filsafat Hukum Islam. Jakarta: Logos Wacana Ilmu. 
Eddyono, S. W. (2019). Politisasi Agama dalam Hukum dan Kebijakan di Era Reformasi Indonesia. Seminar Nasional "Hukum Dan Gagasan Kebangsaan Indonesia Dalam Rangka Pusaran Politik Identitas." Fakultas Hukum Universitas Gadjah Mada.

Effendy, B. (2011). Islam dan Negara: Transformasi Gagasan dan Praktik Politik Islam di Indonesia. Jakarta: Democracy Project.

Elders, L. J. (2019). The Ethics of St. Thomas Aquinas: Happiness, Natural Law, and the Virtues. Washington D.C.: The Catholic University of America Press.

Fauzi. (2018). Sejarah Hukum Islam. Jakarta: Prenada Media Group.

Fitriah, A. (2013). Pemikiran Abdurrahman Wahid tentang Pribumisasi Islam. Teosofi: Jurnal Tasawuf Dan Pemikiran Islam, 3(1).

Hallaq, W. B. (2001). Sejarah Teori Islam. Jakarta: RajaGrafindo Persada.

Hanafi, M. A. (2018). Keadilan dalam Perspektif Filsafat Ilmu Hukum. In Absori (Ed.), Pemikiran Hukum Profetik: Ragam Paradigma Menuju Hukum Berketuhanan. Yogyakarta: Ruas Media.

Johan, T. S. B. (2018). Perkembangan Ilmu Negara dalam Peradaban Globalisasi Dunia. Yogyakarta: Deepublish.

Jumantoro, T. (2005). Kamus Usul Figh. Jakarta: Sinar Grafika.

Kossel, C. G. (2002). "Natural Law and Human Law." In S. J. Pope (Ed.), The Ethics of Aquinas. Washington D.C.: Georgetown University Press.

Kristanto, J. B., \& Arsuka, N. A. (2002). Bentara. Jakarta: Kompas.

Mahfud MD, M. (2011). Perdebatan Hukum Tata Negara Pasca Amandemen Konstitusi. Jakarta: Rajawali Press.

Puri, W. H. (2017). Pluralisme Hukum sebagai Strategi Pembangunan Hukum Progresif di Bidang Agraria di Indonesia. Bhumi, 3(1).

Rosadi, O. (2010). Hukum Kodrat, Pancasila, dan Asas Hukum dalam Pembentukan Hukum di Indonesia. Jurnal Dinamika Hukum, 10(3). 
Sardi, M. (2002). “Kata Pengantar.” In E. Sumaryono (Ed.), Etika dan Hukum: Relevansi Teori Hukum Kodrat Thomas Aquinas. Yogyakarta: Kanisius.

Shidi, G. (2009). Teori Maqashid Al-Syari'ah dalam Hukum Islam. Majalah Ilmiah Sultan Agung, XLIV(118).

Siregar, H. B. (2008). Islamic Law in a National Legal System: A Study on the Implementation of Shari'ah in Aceh, Indonesia. Asian Journal of Comparative Law, 3(1).

Soekarno. (1945). Pidato pada Sidang Badan Penyelidik Usaha-usaha Persiapan Kemerdekaan Indonesia (BPUPKI).

Sudjito. (2007). Refleksi Kritis Atas Teologi Hukum Thomas Aquinas. Diskusi Bulanan Sekolah Pascasarjana Universitas Gadjah Mada.

Sudjito. (2011). Pancasila sebagai Paradigma Ilmu Hukum Indonesia. Seminar Hukum Dan Konstitusi "Pancasila Untuk Pengembangan Dan Pengamalan Ilmu Hukum." Yogyakarta: Pusat Studi Pancasila Universitas Gadjah Mada.

Sudjito. (2016). Ideologi Hukum Indonesia: Kajian tentang Pancasila dalam Perspektif Ilmu Hukum dan Dasar Negara Indonesia. Yogyakarta: Lingkar Media.

Sudjito. (2017). Hukum di Lorong Waktu. Koran Sindo.

Sudjito. (2019a). Keberkahan Hukum: Harapan dan Realitas Kehidupan Manusia. Yogyakarta: Dialektika.

Sudjito. (2019b). Kembali Bersandar pada Hukum Agama. Koran Bernas.

Sunarko, A. (2016). Thomas Aquinas (1225-1274). Kelas Filsafat Abad Pertengahan Komunitas Salihara. Jakarta.

Suseno, F. M. (2003). Etika Politik. Jakarta: Gramedia.

Umar, N. (2019). Antara Negara \& Agama Negara. Retrieved July 22 , 2019, from

https://kemenag.go.id/file/dokumen/AntaraNegara.pdf

Usman, S. (2002). Hukum Islam: Asas-Asas dan Pengantar Studi Hukum Islam dalam Tata Hukum Indonesia. Jakarta: Gaya Media Pratama.

Wahid, A. (1999a). Mengurai Hubungan Agama dan Negara. Jakarta: 
Grasindo.

Wahid, A. (1999b). Tuhan Tidak Perlu Dibela. Yogyakarta: LKiS.

Wahid, M., \& Rumadi. (2001). Fiqh Madzhab Negara: Kritik Atas Politik Hukum Islam di Indonesia. Yogyakarta: LKiS.

Wicaksono, D. A. (2013). Rekonstruksi Pilar Kerangka Hukum dalam Strategi Nasional REDD+ untuk Mewujudkan EkoKonstitusionalisme di Indonesia. Universitas Gadjah Mada.

Zoelva, H. (2009). Negara Hukum dalam Perspektif Pancasila. Kongres Pancasila I. Yogyakarta: Universitas Gadjah Mada Yogyakarta dan Mahkamah Konstitusi Republik Indonesia. 